\title{
Influence of Male to Female Ratio on Hormone Profiles and Reproductive Performance of Anestrus Postpartum Ewes Subjected to the Male Effect
}

\author{
José Carlos Ferreira-Silva', Tracy Anne Burnett ${ }^{2}$, Paulo Francisco Maciel Póvoas Souto', \\ Jorge Motta Rocha ${ }^{3}$, Heder Nunes Ferreira ${ }^{4}$, Marcelo Tigre Moura', \\ Eduardo Luiz Cavalcanti Caldas ${ }^{5}$ \& Marcos Antonio Lemos Oliveira'
}

\begin{abstract}
Background: Complete isolation of genders allows intense estrous induction and synchronization once rams are introduced in ewe flocks at the onset of the breeding season (BS). This management practice, defined as the male effect, results from a neuroendocrine process mediated by pheromones. The male effect is a straightforward procedure to induce estrous in noncycling ewes, but conditions for its use have not been fully explored. Thus, this study aimed to evaluate hormone levels and ovarian activity of postpartum ewes in anestrus which are subjected to the male effect under different male to female ratios. Material, Methods \& Results: Pospartum females were selected according to body condition score and cyclicity status. Females were kept apart from males during 30 days at a distance of $10 \mathrm{~m}$. Anestrus and ovulation were determined by P4 measures on days 10, 20 and 30 after isolation from males. After P4 concentration diagnosis, anestrus ewe $(\mathrm{n}=$ 99) were subjected to male to ewe ratios (MFR) of 1:20 (MFR20), 1:30 (MFR30) and 1:40 (MFR40). Santa Inês rams $(\mathrm{n}=3)$ of proven fertility were used. Three females of each group were randomly subjected to blood collection for $\mathrm{LH}$ concentration analysis. Ovarian activity was performed by ultrasonography after estrus manifestation in six ewe of each group. Estrus events were observed twice a day during the BS of 35 days, and estrus were considered synchronized when it occured within the initial five days of the BS. Pregnancy diagnosis was performed by ultrasonography on days 35 and 60 after the last mating. All ewe were in a non-cycling condition before BS onset, based upon P4 analysis. After initiation of the BS, P4 concentrations increased for all groups. Irrespectively of male to female ratio, male effect induced $\mathrm{LH}$ pre-ovulatory peaks within the initial 26 to $86 \mathrm{~h}$ of the BS. Synchronization of estrus reached $50 \%$ for MFR20, $40 \%$ for MFR30 and 20\% for MFR40 for all ewe. Moreover, overall estrus incidence was 100\% (MFR20), 90\% (MFR30) and 65\% (MFR40) within the initial 15 days of the BS. However, incidence of ewe that had repeated estrus events was lower for MFR20 than for MFR30. Follicular growth and number of ovulations was similar between groups. Conception rates on first service was higher than that of second service for MFR20 and MFR30, although there was no difference between services for MFR40. In contrast, overall conception rates, delivery type and prolificacy were similar between groups.

Discussion: P4 increased to cyclicity levels after contact between genders, demonstrating the potential of the male effect to induce estrus in non-cycling ewes. Most ewe ovulated within three days after the male effect, possibly due to elevated basal LH levels. Moreover, the LH preovulatory peak varied within groups, possibly due to greater interactions between genders, which ultimately may have led to earlier ovulation anticipation under lower MFR. Estrus parameters were similar between groups, suggesting low or negligible effects of MFR. Ovulatory follicle size and growth and the number of ovulations were similar between all groups; previous reports have suggested that this may be due to a strong effect of their genetic background. Conception rates were higher at first than second services, demonstrating the potential of male effect. In conclusion, male to female ratio affects the efficiency of the male effect to induce and synchronize estrus in ewes under postpartum anestrus, but it does not affect conception rates and prolificacy.
\end{abstract}

Keywords: bioestimulation, LH, P4, ovulation, pregnancy, prolificacy.

${ }^{1}$ Departamento de Medicina Veterinária, Universidade Federal Rural de Pernambuco (UFRPE), Recife, PE, Brazil. ${ }^{2}$ Faculty of Land and Food Systems, University of British Columbia, Vancouver, BC, Canada. ${ }^{3}$ Universidade Federal do Rio Grande do Norte (UFRN), Natal RN, Brazil. ${ }^{4}$ Faculdade Pio Decimo, Aracaju, SE, Brazil. ${ }^{5}$ Universidade Federal de Sergipe (UFS), São Cristóvão, SE. CORRESPONDENCE: J.C. Ferreira-Silva [carlos.ztec@ gmail.com - Tel. +55 (81) 3320-6414]. Laboratório de Biotécnicas Aplicadas à Reprodução - UFRPE. Rua Dom Manoel de Medeiros, s/n. Bairro Dois irmãos. CEP 52171900 Recife, PE, Brazil. 


\section{INTRODUCTION}

Sheep production is usually performed under extensive areas that do not favor high reproductive efficiency. Thus, prolonged anestrus postpartum is a limiting factor to livestock production as it negatively affects reproductive rates and overall profitability. On the other hand, anestrus can be easily minimized by adopting appropriate management practices such as the male effect [7,22], which is low cost, easily implemented and fits within animal welfare criteria $[1,2,4,5,9,13]$. Additionally, the male effect may be used as a breeding tool to select females with higher reproductive potential as it has been shown to be associated with reduced age at first delivery and interval between deliveries and increased number of multiple deliveries $[3,19]$.

In general terms, farms in semiarid regions of the northeast of Brazil are small to medium size. This makes it difficult to adopt approaches such as the male effect due to limited distances to isolate genders in order to avoid visual, physical, auditive and olfactive contact [24] for variable periods of time required for male effect $[6,15,27]$. However, recent unequivocal demonstrations have shown that preconditioning distance for the male effect is not a major factor, as it only requires avoidance of physical contact between genders with a minimum distance of $2 \mathrm{~m} \mathrm{[5].}$

In contrast to sexually less active males that may contribute to estrus events of short duration and silenced ovulations [25,26], it is known that males with higher libido induce a greater number of ovulations due to higher interaction with females [6,25]. Moreover, male to female ratio is an important variable of reproductive management since the importance of male fertility on reproduction programs is much greater than any female alone, since males can be mated to several females, independently of mating systems [23].

Due to the fact that male to female ratio is less understood, especially when associated with the male effect, as well as the need to improve current understanding on physiological parameters possibly influenced by this association during the BS, this study aimed to evaluate $\mathrm{P} 4$ and $\mathrm{LH}$ concentration and ovarian activity in anestrus postpartum ewes subjected to the male effect.

\section{MATERIALS AND METHODS}

Experiments were conducted in Escada, Pernambuco state, Brazil. The geographic coordinates were latitude $08^{\circ} 21^{\prime} 33^{\prime \prime} \mathrm{S}$, longitude $35^{\circ} 13$ ' $25^{\prime \prime} \mathrm{O}$. The altitude is $109 \mathrm{~m}$, with a mean annual temperature of $24.4^{\circ} \mathrm{C}$ and mean annual rainfall of $1.763 \mathrm{~mm}^{3}$. The weather is tropical semi-humid, with a rainy period from May to August.

Animals were raised in pastures during the day and kept in a pen late in the afternoon. Animal nutrition was based on cultivated (Brachiaria humidicola) and native pastures (Paspalum maritimum, Chloris orthonton, Cynodon dactylon; Brachiaria tunnergrass) and further supplemented with hay (Pennisetum purpureum) when kept in pens. Animals had free access to mineral salt and water.

Postpartum ewes with 2 to 3 years of age were initially selected and evaluated according to body condition score, and pre-selected with scores from 2 to 3 , as previously described $[4,5]$. The anestrus condition was evaluated by ultrasonography of the reproductive tract in addition to quantification of $\mathrm{P} 4$ concentrations. Blood samples were collected from all ewes on days 10, 20 and 30 after isolation from males. Blood plasma was sampled twice and stored at $-20{ }^{\circ} \mathrm{C}$, until P4 concentration analysis by radioimmunoassay. Females were considered in anestrus when $\mathrm{P} 4$ concentration was lower than $1 \eta \mathrm{g} \mathrm{mL}^{-1}$ in two consecutive samples [18]. After P4 concentration diagnosis, ewes $(n=99)$ were randomly allocated to experimental groups under male to female ratios of 1:20 (MFR20), 1:30 (MFR30) and 1:40 (MFR40). Ewes were identified after selection by numbered plastic earrings and colored neckbands in order to ease management practices. Ewes were kept apart from males for 30 days at a distance of $10 \mathrm{~m}$, avoiding physical contact only [5].

Santa Inês rams $(n=3)$ were selected according to their reproductive performance (proven fertility) and subjected to andrology exam one week before experiment. Rams were marked with a mixture of grease and ink (4:1) around the sternum to facilitate identification of cycling ewes before being introduced in groups. Rams were marked with inks of different colors and were exchanged between groups on days 10, 20 and 30 of the breeding season (BS).

After introduction of rams into ewe flocks, three ewes of each group were randomly subjected to blood collection during a 98-h period in 4-h intervals for $\mathrm{LH}$ concentration analysis. Moreover, these ewes were removed from flocks in order to avoid handling stress effects on their reproductive performance. Blood 
plasma was used to measure $\mathrm{LH}$ and $\mathrm{P} 4$ concentrations. Gonadotropin concentrations were determined by radioimmunoassay, and variations of $20 \eta \mathrm{g} \mathrm{mL}^{-1}$ or higher, within two consecutive samples, were considered significant [16].

Ovulations were confirmed by $\mathrm{P} 4$ concentrations measured on days 10, 20 and 30 of the BS, by methods as described above. Ewes were considered cycling when displayed $\mathrm{P} 4$ concentrations of $1 \eta \mathrm{g} \mathrm{mL}^{-1}$ or higher in two consecutive samples.

Ovarian activity was performed by daily ultrasonographic exams after estrous manifestation in six ewes of each group. Exams were performed by the same technician and moment of ovulation was defined according to previous reports [31].

Estrus events were observed for twice a day (6:00 and 16:00 hours) by trained personnel during the BS of 35 days, and estrus were considered synchronized when they occured within the initial five days of the BS. Pregnancy diagnosis was performed by ultrasonography on days 35 and 60 after the last mating.

Parametric variables were submitted to analysis of variance (ANOVA) and compared by SNK test from System for Statistical Analysis (SAEG) software, with results displayed as means and standard deviation $(\bar{x}$ $\pm \mathrm{s}$ ). Nonparametric variables were evaluated by the chi-square test and displayed as percentages (\%). Level of significance was $5 \%$.

\section{RESULTS}

Table 1 summarizes the data relative to $\mathrm{P} 4$ serum concentration. It can be noted that $\mathrm{P} 4$ concentration were lower than $1 \mathrm{~g} \mathrm{~mL}^{-1}$, indicating that all ewes were in a non-cycling condition before BS onset. It is also possible to verify that after the introduction of rams, ewes began cycling, leading to ovulation and further differences in $\mathrm{P} 4$ levels $(P \leq 0.05)$ in comparison between before and after rams introduction into ewes flocks.

Figure 1 displays data regarding LH serum concentrations after introduction of rams into ewes flocks. It became evident that, irrespectively of male to female ratio, male effect induced LH pre-ovulatory peaks within 26 to $86 \mathrm{~h}$ of the BS onset. Figure 2 contains data related to estrus dispersion that was observed until day 35 of the BS. Estrus onset was dispersed throughout the BS, were $50 \%$ of MFR20 ewes, $40 \%$ of MFR30 ewes and 20\% of MFR40 ewes displayed synchronized estrus. Within the same figure it is possible to note that 100\% (MFR20), 90\% (MFR30) and $65 \%$ (MFR40) of estrus events were detected within the initial 15 days of the BS.

Table 2 contains data concerning estrous manifestation which varied from $70 \%$ to $100 \%$, with no difference $(P \geq 0.05)$ between groups. The number of ewes that repeated estrous within MFR20 and MFR30 was lower $(P \leq 0.05)$ than those that displayed a single estrous. Table 3 demonstrates major findings on ovarian activity, where no difference was found between follicle sizes $(P \geq 0.05)$. Moreover, mean number of ovulations did not differ between groups $(P \geq 0.05)$.

Overall conception rates, as well as conception rates on first and second services are described in Table 4. In contrast to other groups, MFR40 did not display differences between conception rates from fist and second services $(P \geq 0.05)$. The overall conception rates did not differ between groups $(P \geq 0.05)$. Table 5 shows that $98.57 \%$ of pregnant ewes delivered singletons and twins at similar rates $(P \geq 0.05)$. Prolificacy did not differ between groups $(P \geq 0.05)$.

Table 1. Mean $( \pm$ SE) serum P4 concentrations of postpartum Santa Inês ewes in anestrus, before and after mal effect, submitted to male to female ratios of 1:20 (MFR20), 1:30 (MFR30) and 1:40 (MFR40).

\begin{tabular}{|c|c|c|c|}
\hline \multirow[b]{2}{*}{ Group } & \multirow[b]{2}{*}{ Animals (n) } & \multicolumn{2}{|c|}{ P4 Concentration ( $\left.\eta \mathrm{g} \mathrm{mL}^{-1}\right)$} \\
\hline & & $\begin{array}{l}\text { Before } \\
(\bar{x} \pm s)\end{array}$ & $\begin{array}{l}\text { After } \\
(\bar{x} \pm \mathrm{s})\end{array}$ \\
\hline MFR20 & 20 & $0.71 \pm 0.20^{\mathrm{a}}$ & $3.81 \pm 0.25^{\mathrm{b}}$ \\
\hline MFR30 & 30 & $0.66 \pm 0.21^{\mathrm{a}}$ & $3.74 \pm 0.35^{\mathrm{b}}$ \\
\hline MFR40 & 40 & $0.69 \pm 0.15^{\mathrm{a}}$ & $3.66 \pm 0.34^{b}$ \\
\hline
\end{tabular}

Different superscript letters on same line indicate statistical difference $(P \leq 0.05)$. 
J.C. Ferrreira-Silva, T.A. Burnett, P.F.M.P. Souto, et al. 2017. Influence of Male to Female Ratio on Hormones Profiles and Reproductive Performance of Anestrus Postpartum Ewes Subjected to the Male Effect. ActaScientiae Veterinariae.45: 1435.

Table 2. Percentage of single and double estrus events of postpartum ewes in anestrus submitted to male effect, under male to female ratios of 1:20 (MFR20), 1:30 (MFR30) and 1:40 (MFR40).

\begin{tabular}{cccc}
\hline & \multicolumn{3}{c}{ Estrus Type } \\
\cline { 2 - 4 } Group & $\begin{array}{c}\text { Single } \\
\mathrm{n} / \mathrm{n}(\%)\end{array}$ & $\begin{array}{c}\text { Double } \\
\mathrm{n} / \mathrm{n}(\%)\end{array}$ & $\begin{array}{c}\text { Total } \\
\mathrm{n} / \mathrm{n}(\%)\end{array}$ \\
\hline MFR20 & $18 / 20(90.00)^{\mathrm{a}}$ & $2 / 20(10.00)^{\mathrm{b}}$ & $20 / 20(100.00)$ \\
MFR30 & $26 / 30(86.66)^{\mathrm{a}}$ & $4 / 30(13.33)^{\mathrm{b}}$ & $30 / 30(100.00)$ \\
MFR40 & $19 / 40(47.50)^{\mathrm{a}}$ & $9 / 40(22.50)^{\mathrm{a}}$ & $28 / 40(70.00)$ \\
\hline
\end{tabular}

Different superscript letters on same line indicate statistical difference $(P \leq 0.05)$.

Table 3. Mean $( \pm$ SE) ovarian follicular diameter $(\mathrm{mm})$ and number of ovulations of postpartum Santa Inês ewes under anestrus, submitted to male effect under male to female ratios of 1:20 (MFR20), 1:30 (MFR30) and 1:40 (MFR40).

\begin{tabular}{ccccc}
\hline & \multicolumn{4}{c}{ Ovarian Activity } \\
\cline { 2 - 5 } Group & $\begin{array}{c}\text { Diameter of larger } \\
\text { follicle } \\
\left(\bar{x}_{ \pm \mathrm{s}}\right)\end{array}$ & $\begin{array}{c}\text { Diameter of } 2^{\mathrm{o}} \text { larger } \\
\text { follicle } \\
\left(\bar{x}_{ \pm \mathrm{s})}\right.\end{array}$ & $\begin{array}{c}\text { Mean follicular } \\
\text { diameter } \\
\left(\bar{x}_{ \pm \mathrm{s}}\right)\end{array}$ & $\begin{array}{c}\text { Number of } \\
\text { ovulations } \\
\left(\bar{x}_{ \pm \mathrm{s}}\right)\end{array}$ \\
\hline MFR20 & $7.35 \pm 0.62$ & $6.60 \pm 0.58$ & $6.97 \pm 0.69$ & $1.66 \pm 0.51$ \\
MFR30 & $7.33 \pm 0.59$ & $6.45 \pm 0.48$ & $6.89 \pm 0.69$ & $1.50 \pm 0.54$ \\
MFR40 & $7.43 \pm 0.88$ & $6.33 \pm 0.25$ & $6.88 \pm 0.84$ & $1.33 \pm 0.51$ \\
\hline
\end{tabular}

Table 4. Pregnancy per service of postpartum Santa Inês ewes under anestrus submitted to male effect under male to female ratios of 1:20 (MFR20), 1:30 (MFR30) and 1:40 (MFR40).

\begin{tabular}{cccc}
\hline \multirow{2}{*}{ Group } & \multicolumn{3}{c}{ Pregnancies per Service } \\
\cline { 2 - 4 } & First n/n $(\%)$ & Second $\mathrm{n} / \mathrm{n}(\%)$ & Total $\mathrm{n} / \mathrm{n}(\%)$ \\
\hline MFR20 & $17 / 18(94.44)^{\mathrm{a}}$ & $2 / 2(100.00)^{\mathrm{b}}$ & $19 / 20(95.00)$ \\
MFR30 & $23 / 26(88.46)^{\mathrm{a}}$ & $3 / 4(75.00)^{\mathrm{b}}$ & $26 / 30(86.66)$ \\
MFR40 & $16 / 28(64.28)^{\mathrm{a}}$ & $9 / 9(100.00)^{\mathrm{a}}$ & $25 / 28(89.28)$ \\
\hline
\end{tabular}

Different superscript letters on same line indicate statistical difference $(P \leq 0.05)$.

Table 5. Percentage of delivery type and prolificacy of postpartum Santa Inês ewes under anestrus, submitted to male effect under male to female ratios of 1:20 (MFR20), 1:30 (MFR30) and 1:40 (MFR40).

Delivery Type

\begin{tabular}{ccccc} 
Group & $\begin{array}{c}\text { Singleton } \\
\mathrm{n} / \mathrm{n}(\%)\end{array}$ & $\begin{array}{c}\text { Twins } \\
\mathrm{n} / \mathrm{n}(\%)\end{array}$ & $\begin{array}{c}\text { Total } \\
\mathrm{n} / \mathrm{n}(\%)\end{array}$ & $\begin{array}{c}\text { Prolificacy } \\
(\overline{\boldsymbol{x}} \pm \mathrm{s}\end{array}$ \\
\hline MFR20 & $9 / 19(47.37)$ & $10 / 19(52.63)$ & $19 / 19(100.00)$ & $1.52 \pm 0.51$ \\
MFR30 & $11 / 26(42.31)$ & $14 / 26(53.84)$ & $25 / 26(96.15)$ & $1.56 \pm 0.50$ \\
MFR40 & $13 / 25(52.00)$ & $12 / 25(48.00)$ & $25 / 25(100.00)$ & $1.48 \pm 0.50$ \\
\hline
\end{tabular}




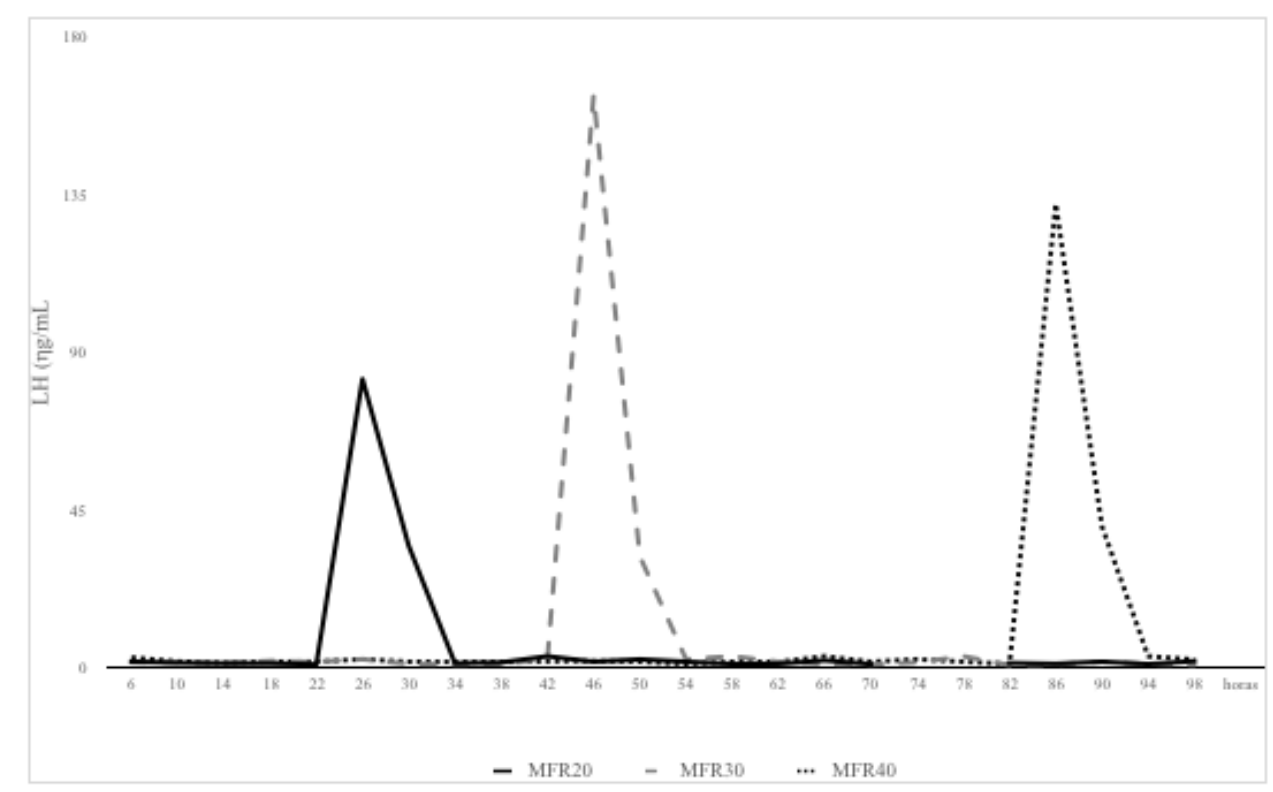

Figure 1. Concentration of $\mathrm{LH}\left(\eta \mathrm{gL}^{-1}\right)$, during the period from 6 to 98 hours after the onset of the male effect, in postpartum Santa Inês ewes under anestrus, submitted to male effect under male to female ratios of 1:20 (MFR20), 1:30 (MFR30) and 1:40 (MFR40).

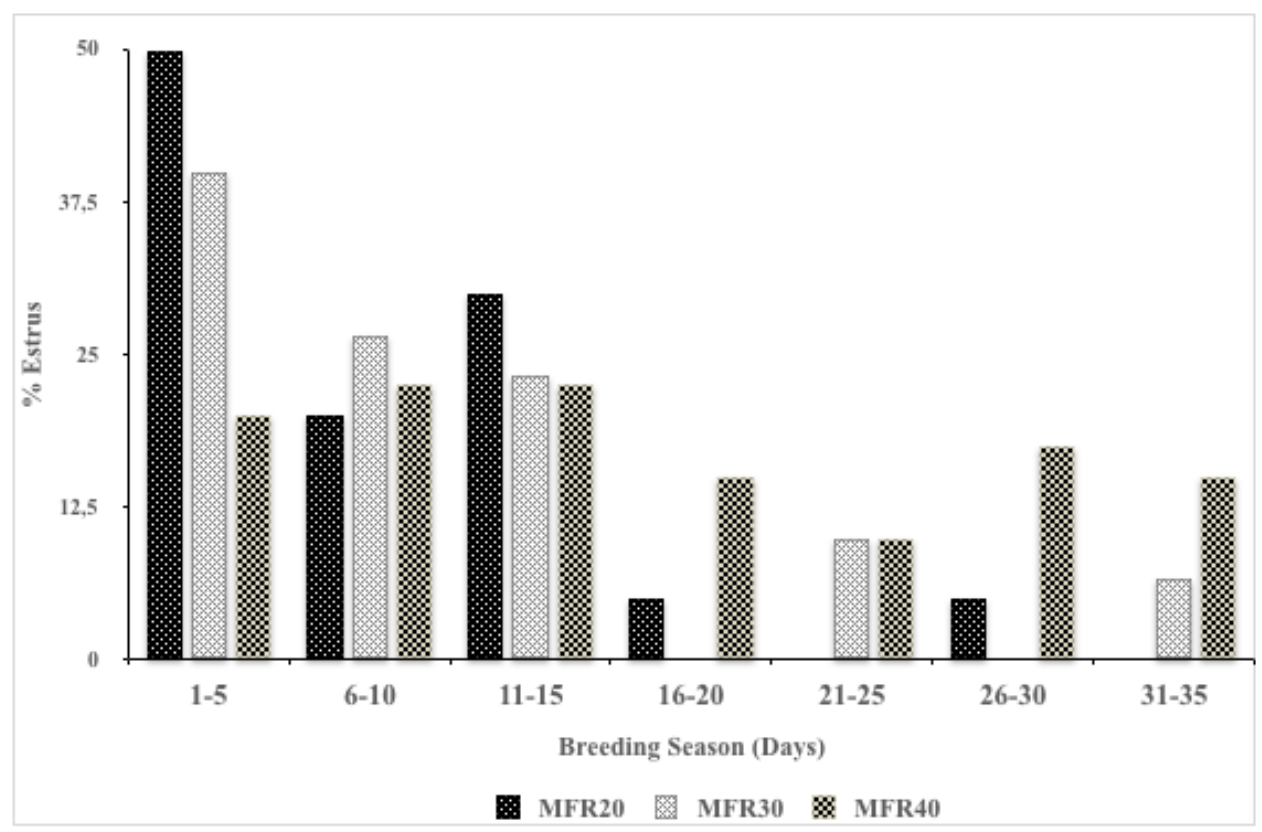

Figure 2. Estrus distribution in postpartum Santa Inês ewes under anestrus, submitted to male effect, under male to female ratios of 1:20 (MFR20), 1:30 (MFR30) and 1:40 (MFR40).

\section{DISCUSSION}

As suggested earlier [18], P4 mean concentrations immediately before BS onset within all experimental groups were according to females in a non-cycling condition. P4 mean values after contact between genders increased to levels common to cycling condition, demonstrating the effectiveness of the male effect to induce fertile estrus in non-cycling ewes under postpartum anestrus.
A high percentage of ewes ovulated within a $72 \mathrm{~h}$ period after exposure to rams, probably due to elevated basal LH levels [21] that increased ewes sensibility to stimulation [14]. Estrus that was followed by ovulation were due to $\mathrm{LH}$ peaks that occurred in a dispersed fashion in all groups. Moreover, preovulatory LH peak in the MFR20 group occurred before the remaining groups: $20 \mathrm{~h}$ before MFR30 and $60 \mathrm{~h}$ before MFR40. Since rams were submitted to an andrology 
exam, in which libido was also evaluated, it is possible that lower male to female ratios led to greater interaction between genders that ultimately led to ovulation anticipation. This hypothesis was established based upon the argument that rams with increased libido raise male effect efficiency by inducing a higher number of ovulations due to increased interaction with ewes $[20,25]$.

Despite the fact that estrus was observed for until day 35 of the BS, it is necessary to note a relevant synchronization rate in MFR20 and MFR30 groups, possibly due to higher male to female ratios. It is important to note that the male effect, irrespectively of groups, was efficient at concentrating estrus in most ewes within the initial 15 days of the BS, a relevant aspect in a production system as it lowers costs needed for trained personnel to observe for estrus, concentrates deliveries under favorable periods, results in uniform lots of animals and allows ovine production planning in accordance with market demands [10]. Another important aspect is that the majority of females on MFR20 and MFR30 groups exhibited a single estrus followed by formation of corpus luteum with physiological viability in contrast to MFR40. Moreover, only $70 \%$ of MFR40 ewes displayed estrus, showing the importance of the male to female ratio during the BS. The findings described on the prevalence of singletons over twin deliveries was contrary to previous results [17]. Moreover, data on prolificacy is similar to other findings with Santa Inês ewes pluriparous [12] and nuliparous [30].

Two independent groups registered ovulatory follicles varying from 5.1 to $5.7 \mathrm{~mm}$ for wooled sheep breeds $[8,11]$. As described here, the diameter of the ovulatory follicle was larger then previously described for Santa Inês ewes [28]. It is relevant to consider that ovulatory follicle size and the number of ovulations was similar between all groups, showing that male to female ratio did not influence such factors, that may ultimately be related to their genetic background, although, Nelore beef cattle where shown to have an increased follicular diameter when females were subjected to biostimulation [29].

Conception rate on first service was higher than that of the second service on MFR20 and MFR30 groups where the interaction between genders was higher. This finding demystifies the observation that the first estrus due to the male effect could be anovulatory [32] or, if ovulation occurs, corpum luteum is weak, lapses rapidly and leads to occurrence of short estrus cycles [6]. Moreover, it shows that male to female ratios of 1:30 or higher, even under controlled mating, should be reanalyzed and considered for adoption even if total conception rates did not differ between groups. What may have occurred in MFR40 is that a concentration of estrus events occurred in a large number of ewes, making it demanding for the ram within the initial 15 days of the BS, a fact that may have contributed to similar pregnancy rates on both services.

\section{CONCLUSIONS}

The results described here allow the conclusion that male to female ratio affects the efficiency of the male effect to induce and synchronize estrus in ewes under postpartum anestrus, but does not affect conception rates and prolificacy.

\section{MANUFACTURER \\ ${ }^{1}$ Aquila Pro, Pie Medical Imaging. Masstrich, the Netherlands.}

Acknowledgements. The work was financially supported by CAPES and CNPq.

Ethical approval. This research was performed after evaluation and approval of the Ethics Committee of the Faculdade Pio Décimo, Aracaju-Se, Brazil, with protocol nº 08/12.

Declaration of interest. The authors declare that they have no conflict of interest and are available to provide any clarification.

\section{REFERENCES}

\section{Almeida-Irmão J.M., Ferreira-Silva J.C, Silva P.G.C., Freitas Neto LM., Moura M.T., Oliveira L.R.S. \& Lima}

P.F. \&Oliveira M.A.L. 2014. Efeito do desaleitamento temporário e do efeito macho sobre a reprodução de caprinos. Medicina Veterinária. 8: 24 - 30.

2 Alves C.G.T., Ferreira-Silva J.C., Almeida-Irmão J.M., Moura M.T., Bartolomeu C.C., Lima P.F. \& Oliveira M.A.L. 2015. Reproductive outcomes using different distances for preconditioning for the male effect in Anglo Nubian goats during two distinct climate seasons. Boletim de Indústria Animal. 72(1): 69-76.

3 Azzarini M. 2004. Potencial reproductivo de los ovinos. Producción Ovina. 16: 5-17. 
4 Caldas E.L.C., Ferreira-Silva J.C., Freitas Neto L.M., Veloso Neto H.F., Moura M.T., Lima P.F., Santos M.H.B. \& Oliveira M.A.L. 2015. Male effect associated with suckling interruption on the reproductive performance of Santa Inês ewes. Boletim de Indústria Animal. 72: 117-123.

5 Caldas E.L.C., Freitas Neto L.M., Almeida-Irmão J.M., Ferreira-Silva J.C., Silva P.G.C., Veloso Neto H.F., Neves J.P., Moura M.T., Lima P.F. \& Oliveira M.A.L. 2015. The influence of separation distance during the preconditioning period of the male effect approach on reproductive performance in sheep. Veterinary Science Development. 4: 1-9.

6 Chemineau P., Pellicer-Rubio M.T., Lassoued N., Khaldi G.E. \& Monniaux D. 2006. Male-induced short oestrous and ovarian cycles and sheep and goats: a working hypothesis. Reproduction NutritionDevelopment. 46: 417-429.

7 De St. Jorre T.J., Hawken P. \& Martin G.B. 2014. New understanding of an old phenomenon: uncontrolled factors and misconceptions that cast a shadow over studies of the 'male effect'on reproduction in small ruminants. Turkish Journal of Veterinary and Animal Sciences. 38(6): 625-636.

8 Evans A.C.O., Duffy P., Hynes N. \& Boland M.P. 2000. Waves of follicle development during the estrous cycle in sheep. Theriogenology. 53: 699-715.

9 Falcão D.P., Santos M.H.B., Freitas Neto L.M., Neves J.P., Lima P.F. \& Oliveira M.A.L. 2008. Uso da PGF2 no puerpério para reduzir o anestro pós-parto de cabras em aleitamento contínuo e controlado. Ciência Animal Brasileira. 9: 512-518.

10 Fonseca J.F. 2005. Estratégias para o controle do ciclo estral e superovulação em ovinos e caprinos. Revista Brasileira de Reprodução Animal. 16: 1-9.

11 Ginther O.J., Kot K. \& Wiltbank M.C. 1995. Associations between emergence of follicular waves and fluctuations in FSH concentrations during the estrous cycle in ewes. Theriogenology. 43: 689-703.

12 Machado I.B.B., Fernandes A.A.O. \& Selaive-Villarroel A.B. 1999. Parâmetros reprodutivos de ovinos deslanados Morada Nova e Santa Inês mantidos em pastagem cultivada no estado do Ceará. Revista Científica de Produção Animal. 1: 81-87.

13 Martin G.B. \& Kadokawa H. 2006. "Clean, Green and Ethical” Animal Production. Case Study: Reproductive Efficiency in Small Ruminants. Journal of Reproduction and Development. 52: 145-152.

14 Martin G.B., Oldham C.M. \& Lindsay D.R. 1980. Increased plasma LH levels in seasonally anovular Merino ewes following the introduction of rams. Animal Reproduction Science. 3: 25-132.

15 Martin G.B., Oldham C.M., Cognié Y. \& DT Pearce. 1986. The physiological responses of an ovulatory ewes to the introduction of rams-A review. Livestock Production Science. 15: 219-247.

16 Martin G.B., Scaramuzzi R.J. \& Henstridge J.D. 1983. Effects of oestradiol, progesterone and androstenedione on the pulsatile secretion of luteinizing hormone in ovariectomized ewes during spring and autumn. Journal of Endocrinology. 96: 181-193.

17 Mexia A.A., Macedo F.A.F, Alcalde C.R., Sakaguti E.S., Martins E.N., Zundt M., Yamamoto S.M. \& Macedo R.M.G. 2004. Desempenhos Reprodutivo e Produtivo de Ovelhas Santa Inês Suplementadas em Diferentes Fases da Gestação. Revista Brasileira de Zootecnia. 33: 658-667.

18 Morales J.U., Vaquez H.G.G. \& Andrade. B.M.R. 2003. Influencia del pastoreo restringido en el efecto macho em cabras em baja condición corporal durante la estación de anestro. Técnica Pecuária en México. 41: 251-260.

19 Notter D.R. \& Copenhaver J.S. 1980. Performance of Finnish Landrace crossbred ewes under accelerated lambing. II. Lamb growth and survival. Journal Animal Science. 51: 1043-1050.

20 Okamura H., Murata K., Sakamoto K., Wakabayashi Y., Ohkura S., Takeuchi Y., Mori Y. 2010. Male Effect Pheromone Tickles the Gonadotrophin Releasing Hormone Pulse Generator. Journal of Neuroendocrinology. 22: 825-832.

21 Oldham C., Martin. G.B. \& Knight T.W. 1979. Stimulation of seasonally anovular Merino ewes by rams. I. Time from introduction of the rams to the preovulatory LH surge and ovulation. Animal of Reproduction Science. 1: 283-290.

22 Oliveira L.R.S., Ferreira-Silva J.C., Chaves M.S., Freitas Neto L.M., Moura M.T., Caldas E.L.C., Lima P.F. \& Oliveira M.A.L. 2015. Male Efect and Breeding Season Shortening Under Contrasting Climatic Conditions Upon Reproduction of Nulliparous Anglo-Nubians. Ciência Veterinária nos Trópicos. 18: 43-48.

23 Pacheco A., Quirino C.R. \& Oliveira A.F.M. 2010. Assessment of sexual behavior of young rams of Santa Inês breed, with and without prior experience with females. Archivos Latinoamericanos de Producción Animal. 17: 15-24.

24 Pearce D.T. \& Oldham C.M. 1988. Importance of non-olfatory ram stimuli in mediating ram-induced ovulation in the ewe. Journal of Reproduction and Infertility. 84: 333-339. 
J.C. Ferrreira-Silva, T.A. Burnett, P.F.M.P. Souto, et al. 2017. Influence of Male to Female Ratio on Hormones Profiles and Reproductive Performance of Anestrus Postpartum Ewes Subjected to the MaleEffect. ActaScientiae Veterinariae.45: 1435.

25 Perkins A. \& Fitzgerald J.A. 1994. The Behavioral Component of the Ram Effect: The Influence of Ram Sexual Behavior on the Induction of Estrus in Anovulatory Ewes. Journal of Animal Science. 72: 51-55.

26 Ramirez L.A. \& Quintero L.A.Z. 2001. Los fenómenos de bioestimulacion sexual en ovejas y cabras. Veterinaria Mexico. 32: 117-129.

27 Rosa H.J.D. \& Bryant M.J. 2002. The 'ram effect' as a way of modifying the reproductive activity in the ewe. Small Ruminant Research. 45: 1-16.

28 Saunders G.D.A., Alves N.G., Pérez J.R.O., Souza J.C.D., Muniz J.A. \& José Neto A. 2010. Effect of flushing with sources of protein with different degratability on ovulation in Santa Inês ewes. Revista Brasileira de Zootecnia. 39: 2731-2738.

29 Silva Filho M.L., Bezerra L.R., Ferreira-Silva J.C., Souto, P.F.M.P., Paula, N.R.O., Lima, P.F., Bartolomeu C.C. \& Oliveira M.A.L. 2015. Influence of biostimulation and temporary weaning on follicular dynamics and pregnancy rates in Nelore cows (Bos taurus indicus). Tropical Animal Health and Production. 47: 1-7.

30 Tenório Filho F., Ferreira-Silva J.C., Nascimento P.S., Freitas Neto L.M., Moura M.T., Almeida Irmão J.M. \& Oliveira M.A.L. 2016. Ação do efeito macho sobre a eficiência reprodutiva de ovelhas nulíparas das raças Santa Inês e Morada Nova criadas em diferentes regiões. Acta Scientiae Veterinariae. 44: 1353.

31 Tenório Filho F., Santos M.H.B., Carrazzoni P.G., Bartolomeu C.C., Lima P.F. \& Oliveira M.A.L. 2007. Follicular dynamics in Anglo-Nubian goats using transrectal and transvaginal ultrasound. Small Ruminant Research. 72: 51-56.

32 Ungerfeld R., Dago A.L., Rubianes E. \& Forsberg M. 2004. Response of anestrous ewes to the ram effect after follicular wave synchronization with a single dose of estradiol-17 . Reproduction Nutrition Development. 44: 89-98. 